\title{
土構造物の振動特性に及ぼす基礎地盤の影響 \\ EFFECT OF GROUND CONDITION ON VIBRATIONAL CHARACTERISTICS OF EARTH STRUCTURE
}

\author{
柳 沢 栄 司* \\ By Eiji YANAGISAWA
}

\section{1. まえがき}

軟弱地盤上に構築された河川堤防や干拓堤防などが大 地震に際して多大な被害を被った例は数多くあり，ま た，地盤条件のよくない箇所に建設された比較的小規模 のアースダムや土堰堤などに震害が発生した例も数多く 報告されている。このような土構造物の地震時の安全性 に及ぼす地盤条件の影響はきわめて大きく，堰堤の耐震 性の評価に際しては十分考慮される必要がある.

各種構造物と震害と地盤の関係については古くから注 目されており，木造家屋の倒壊率と地盤との関係 ${ }^{1)}$, 地 表土層の厚さと木造家屋の震害との関倸 ${ }^{2)}$, あるいは常 時微動の性質と木造家屋の震害との関係など ${ }^{3), 4)}$ に相関 性があることが指摘されている.土構造物の震害につい ても，軟弱地盤の厚さとの関係や常時微動の卓越周期と の関連性について研究が行われており, 地盤と震害との 強い相関が指摘されている.たとえば, 1964 年男鹿西方 沖地震に際して八郎潟干拓堤防は多大な被害を受けた が，軟弱地盤の厚い地点では震害が著しいことが指摘さ れている.また, 1964 年新潟地震に際して生じた最上 川堤防の被害についても軟弱地盤の影響が大きいことが 報告されている て生じた鉄道盛土の被害について要因分析を行い，盛土 の被害と地形および地盤条件との間に強い相関性が認め られるとの報告を行っている。このように土構造物の被 害に及ぼす基礎地盤の影響はきわめて大きく，士構造物 の耐震性を考慮するうえで地盤の影響を無視することは できない.

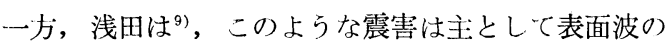
影響であるとの仮定に立ち， Reighley 波の波長と震害: の実態とがよく対応するとの報告を行っている.また， 神山によれば, 地盤内のひずみの大きさからみて, 工学

* 正会員 工博 東北大学助教授 工学部土木工学科
的にも表面波の影響は無視し得ないことが指摘されてい $る^{10)}$. しかしながら，表面波は地形や土層など形状の影 響を受けやすく，表面波による被害の害態を調べること は不可能に近い，また，地震時の表面波の応答を求める ことはかなり煩雑であり, 構造物を含めた応答解析を行 うことはきわめて困難である.これに対し，従来から用 いられている S 波の応答解析法は簡便であり，から，地 震忘答を近似的に求める手法として有効であることが確 立されているなどの利点がある。よって，ここでは表面 波の影響については無視し，S波に対する堤体の态答特 性を求めて,地盤の影響について考察を行うこととした。

いま，水平な基盤上にいく層かの平行堆積層のある多 層地盤を考えてこの上に三角形の堤体が築造されている ものと仮定し，この土構造物一地盤系に鉛直下方からせ 儿断波が入射したときの定常応答を解析的に求めた.こ の場合, 堤体・地盤ともにせん断変形のみするものと仮 定しているが，このようないわゆるせん断くさび理論は 変位の方向が一方向に限られているために，他の二次元 あるいは三次元的な解析方法に比べて実情に合わない点 が多い，すなわち，堤軸方向および上下方向の変位成分 が無視されているため地震時の堤体の挙動が正確には表 わされないばかりでなく, 地盤を堤体の底敷幅に等しい 土柱と考えて振動方程式を求めているために，堤体の斜 面勾配の影響が無視されることおよび地表面全体に堤体 が载っているよらなモデルとなることなど不合理な点も 多い。立た，堤体の形状が複雑な場合や堤体の断面内で 構成材料が異なる場合などについては考慮できないなど の欠点もある。しかしながら，このせん断くさび理論汒 堤体中心部に抢ける堤軸直角方向の堤体の挙動を近似的 に表わし得ること㧍よび差分法や有限要素法と異なり解 析的な解が得られるなどの特色があり，簡明な仮定とし てよく用いられている.この定常応答解により, 堤体頂 部での応答特性が基礎地盤の振動特性によって大きく影 響されることおよび動的相互作用のため堤体一地盤系の 
振動は堤体拉よび地盤のそれぞれの個別の振動を重ね合 わせたものとは異なることなどが確かめられた。この結 果を用いて簡単な二層地盤モデルについて試算を行い， 堤体と地表層の剛性の差異によって振動特性がどのよう に変化するかについて検討を行った．また，上記の結果 を忘用して八郎潟中央干拓堤防を例にとり地中常時微動 や地震記録などの実測值と理論値との比較を行い，両者 の値の相似性からこの解析手法が有効であることを示し た.さらに, 地震応答解析の一例として, この干拓堤防 について加速度応答を求め, 最大加速度応答倍率に及ぼ す軟弱層の厚さの影響についても論じた.

\section{2. 堤体の振動に及ぼす地表層の影響}

\section{（1）二層地盤上の堤体の振動}

土構造物の地震応答特性は, 基礎地盤の硬軟によって きわめて大きく影響されることはすでに述べたとおりで ある. 岡本は ${ }^{11)}$, 基礎地盤上に三角形の堤体を考光, 鉛 直下方加 入射するせん断波に対する応答を求めてい る.この結果によれば, 波の地下逸散による減衰がかな り大きく，堤体と地盤とのインピーダンス比 $\alpha$ にっ て堤体の态答倍率にかなり差異があることが示されてい る.しかし, 河川堤防や干拓堤防のような土構造物は通 常沖積平野部に築造される場合が多く，上記の岩盤上の 堤体とは異なって地表層の振動の影響を受けることが考 えられる ${ }^{12)}$. 沖積地艗は一般に多くの土層からなり，堆 積の過程によって複雑な構造をもっているが，簡単のた めここでは唯積層は水平で均質な弾性体からなっている ものとする．いま，図一1 に示すような基盤層の上に水 平に堆積している比較的軟らかい地表層とさらにその上 に築造された三角形の堤体のモデルを考え, 土構造物の 高さを $H$ ，地表層の厚さを $h$ とし，この堤体一地盤系 に鉛直下方からせん断波が入射するものとする．堤体モ デルとしては，本来，より現実に近いせつ頭くさびの形 状を考えるべきであるが，解が複雑になることおよび 考慮すべきパラメーターが多くなりすぎるなどの理由か
ら，ここでは単純な三角形体と仮定した.

堤体敌よび地盤はせん断変形のみするものと仮定し， 地盤内に上昇する波と下降する波を考光，これらを余弦 波として表わす．このときの基盤層，地表層および堤体 内の変位をそれぞれ $Y_{1}, Y_{2}$ 扎よび $Y_{3}$ で示せば，

$$
\begin{aligned}
Y_{1}= & A_{1} \cos \left\{P\left(t-\frac{z-H-h}{V_{1}}\right)-\phi_{1}\right\} \\
& +B_{1} \cos \left\{P\left(t+\frac{z-H-h}{V_{1}}\right)-\phi_{2}\right\} \\
Y_{2}= & A_{2} \cos \left\{P\left(t-\frac{z-H}{V_{2}}\right)-\psi_{1}\right\} \\
& +B_{2} \cos \left\{P\left(t+\frac{z-H}{V_{2}}\right)-\psi_{2}\right\} \\
Y_{3}= & \left.Y_{2}\right|_{z=H}+\xi
\end{aligned}
$$

である。

堤体の基礎面すなわち地表面 $(z=H)$ での振動を位 相の基準にとれば，堤体底面での振動 $\left.Y_{2}\right|_{z=H}$ は $U_{0} \cos$ $P t$ と扔ける. したがって, 堤体の相対変位 $\xi$ は, 従来 のせん断くさびの振動理論を用いて強制定常振動の解を 求めることができる.この解は,

$$
\xi=\sum_{i} F_{i}(z) \cdot Q_{i}(t)
$$

ここに,

$$
\begin{aligned}
& F_{i}(z)= J_{0}\left(\frac{P_{i} z}{V_{3}}\right)=J_{0}\left(\frac{z_{i} z}{H}\right) \\
& Q_{i}(t)= \frac{\mu_{i}\left(\frac{P}{P_{i}}\right) U_{0}}{\left\{1-\left(\frac{P}{P_{i}}\right)^{2}\right\}^{2}+\left(\frac{\eta P}{G}\right)^{2}} \\
& \cdot\left[\left\{1-\left(\frac{P}{P_{i}}\right)^{2}\right\} \cos P t+\frac{\eta P}{G} \sin P t\right] \\
& P_{i}=\frac{z_{i} V_{3}}{H}
\end{aligned}
$$

$\mu_{i}$ は $i$ 次の刺激関数, $J_{0}$ は 0 次のベッセル関数, $z_{i}$ は $J_{0}$ の $i$ 番目の根, $V_{3}$ は堤体材料のせん断波速度で ある。

各土層の境界面に扔いて変位およびせん断力が連続で あることから，式 (1) に含まれる波の振幅は入力余弦波 の振幅 $A_{1}$ の関数として与えられる. 堤体の頂部におけ る振幅 $A_{c}$ の入力波の振幅 $A_{1}$ に対する振幅比すなわち 堤頂に扔汀る応答倍率は,

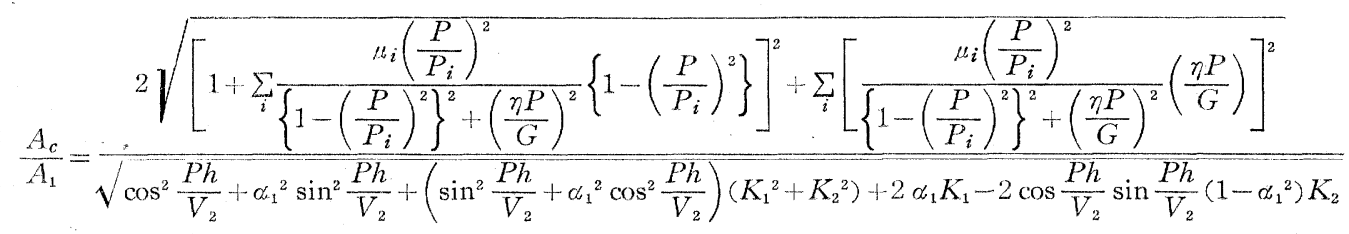

で示される. 堤体底面での振幅 $U_{0}$ と入力波の振幅 $A_{1}$ との比は,

$$
\frac{U_{0}}{A_{1}}=\frac{2}{\sqrt{\cos ^{2} \frac{P h}{V_{2}}+\alpha_{1} \sin ^{2} \frac{P h}{V_{2}}+\left(\sin ^{2} \frac{P h}{V_{2}}+\alpha_{1}{ }^{2} \cos ^{2} \frac{P h}{V_{2}}\right)\left(K_{1}{ }^{2}+K_{2}{ }^{2}\right)+2 \alpha_{1} K_{1}-2 \cos \frac{P h}{V_{2}} \sin \frac{P h}{V_{2}}\left(1-\alpha_{1}{ }^{2}\right) K_{2}}} \cdots
$$




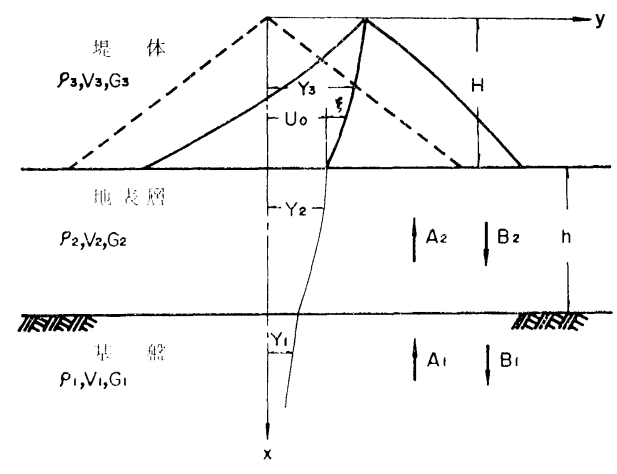

图 1 堤体と地盤のモデル

であり，また，堤体底面の振幅 $U_{0}$ と基盤面の絶対振帽

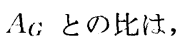

$$
\frac{\frac{U_{0}}{A_{c}}=}{\sqrt{\cos ^{2} \frac{P h}{V_{2}}-2 \cos \frac{P h}{V_{2}} \sin \frac{P h}{V_{2}} K_{2}+\sin \frac{P h}{V_{2}}\left(K_{1}{ }^{2}+K_{2}{ }^{2}\right)}}
$$

で示される. ここに， $K_{1}$ および $K_{2}$ は堤体の振動が地 盤に及ぼす影響を示すパラメーターであり，

$$
\begin{aligned}
K_{1}= & \alpha_{2} \sum_{i} \frac{\mu_{i}\left(\frac{P}{P_{i}}\right)^{2}}{\left\{1-\left(\frac{P}{P_{i}}\right)^{2}\right\}^{2}+\left(\frac{\eta P}{G}\right)^{2}} \\
& \cdot\left(\frac{\eta P}{G}\right)\left(\frac{P}{P_{i}}\right) J_{1}\left(z_{i}\right) \\
K_{2}= & \alpha_{2} \sum_{i} \frac{\mu_{i}\left(\frac{P}{P_{i}}\right)^{2}}{\left\{1-\left(\frac{P}{P_{i}}\right)^{2}\right\}^{2}+\left(\frac{\eta P}{G}\right)^{2}} \\
& \cdot\left\{1-\left(\frac{P}{P_{i}}\right)^{2}+\left(\frac{\eta P}{G}\right)^{2}\right\}\left(\frac{P_{i}}{P}\right) J_{1}\left(z_{i}\right) \\
\mu_{i}= & \frac{2}{z_{i} J_{1}\left(z_{i}\right)}, \alpha_{1}=\frac{\rho_{2} V_{2}}{\rho_{1} V_{1}}, \alpha_{2}=\frac{\rho_{3} V_{3}}{\rho_{2} V_{2}}
\end{aligned}
$$

ここに， $\rho, V$ はそれぞれ密度およびせん断波速度を表 わすが, その添字 1,2 および 3 はそれぞれ基盤層, 地 表層および堤体の材質を示す. $G$ および $\eta$ はそれぞれ 堤体材料の剛性率および減衰定数であり, $P$ は余弦入 力波の円振動数である. 堤体の地震応答は, 式 (3) から も明らかなように主として堤体の剛性と減衰性および高 さ，地表層の剛性と厚さおよび基盤層の剛性の関数とし て与えられている. 式 (3) において分子項は堤体自身の 応答を示すものであり, また, 分母項は堤体振動に及ぼ す地盤振動の影響を示すものである. 式 (4) および (5) において分母項中の $K_{1}$ および $K_{2}$ を含む項は地盤振動 に及ぼす堤体の振動を示す項であり，もし堤体の影響が ない場合を考えて $K_{1}$ および $K_{2}$ を 0 と仮定すれば，よ く知られた二層地盤の応答の式に一致し, 土構造物と地 盤の動的相互作用が数式的に理解される.

\section{（2）多層地盤上の堤体の振動}

前節で述べたと同様な考方方を用いて多層地盤上の堤 体の振動を解くことができる. 基盤上に $n$ 層の堆積層が ある場合, $2 n+1$ 元の連立方程式を解くことになるの で, 一般的な解を求めることは困難であるが, 個々の閣 題については定常応答を求めることは叮能である.ここ では水平な基盤上に平行に婎積した三層の地表層がある 場合の四層地盤モデルについて考える。－二層地盤のとき と同様に各層の境界で変位と力が等しいことから，基盤 の入力波の振幅 $A_{1}$ に対する堤体頂部における态答の振

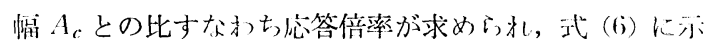
寸上らな形となる。

$$
\frac{\Lambda_{c}}{A_{1}}=\frac{2 \sqrt{\left(1+\sum_{i}\left(C_{i} I\right)_{i}\right)^{2}+\left(\sum_{i} C_{i} K_{i}\right)^{2}}}{\sqrt{ } B}
$$

$=-k$,

$$
\begin{aligned}
C_{i}= & \frac{\mu_{i}\left(\frac{P}{P_{i}}\right)^{2}}{D_{i}{ }^{2}+E_{i}{ }^{2}}, D_{i}=1-\left(\frac{P}{P_{i}}\right)^{2}, E_{i}=\frac{\eta P}{G} \\
B= & \left(r_{2}{ }^{2}+\alpha_{1}{ }^{2} s_{2}{ }^{2}\right)\left(r_{3} r_{4}-\alpha_{3} s_{3} s_{4}\right)^{2}+\alpha_{2}{ }^{2}\left(s_{2}{ }^{2}\right. \\
& \left.+\alpha_{1} r_{2}{ }^{2}\right)\left(r_{4} s_{3}+\alpha_{3} r_{3} s_{4}\right)^{2}-2 \alpha_{2}\left(1-\alpha_{1}{ }^{2}\right) \\
& \cdot r_{2} s_{2}\left(r_{4} s_{3}+\alpha_{3} r_{3} s_{4}\right)\left(r_{3} r_{4}-\alpha_{3} s_{3} s_{4}\right) \\
& +\left(K_{1}{ }^{2}+K_{2}{ }^{2}\right)\left\{\left(r_{2}{ }^{2}+\alpha_{1}{ }^{2} s_{2}{ }^{2}\right)\left(r_{3} s_{4}+\alpha_{3} r_{4} s_{3}\right)\right. \\
& +\alpha_{2}{ }^{2}\left(s_{2}{ }^{2}+\alpha_{1} r_{2}{ }^{2}\right)\left(\alpha_{3} r_{3} r_{4}-s_{2} s_{4}\right)^{2} \\
& +2 \alpha_{2}\left(1-\alpha_{1}\right) r_{2} s_{2}\left(r_{3} s_{4}+\alpha_{3} r_{4} s_{3}\right)\left(\alpha_{3} r_{3} r_{4}\right. \\
& \left.\left.-s_{2} s_{4}\right)\right\}+2 \alpha_{1} \alpha_{2} \alpha_{3} K_{1}-2 K_{2}\left[\left(r_{2}+\alpha_{1}{ }^{2} s_{2}\right)\right. \\
& \cdot\left(r_{3} s_{4}+\alpha_{3} r_{4} s_{3}\right)\left(r_{3} r_{4}-\alpha_{3} s_{3} s_{4}\right)-\alpha_{2}{ }^{2}\left(s_{2}{ }^{2}\right. \\
& \left.+\alpha_{1}{ }^{2} r_{2}{ }^{2}\right)\left(r_{4} s_{3}+\alpha_{3} r_{3} s_{4}\right)\left(\alpha_{3} r_{3} r_{4}-s_{3} s_{4}\right) \\
& -2 \alpha_{2}\left(1-\alpha_{1}{ }^{2}\right) r_{2} s_{2}\left\{\alpha_{3}\left(s_{3}{ }^{2}-r_{3}{ }^{2}\right)\left(r_{4}{ }^{2}-s_{4}{ }^{2}\right)\right. \\
& \left.\left.+2\left(1+\alpha_{3}\right) r_{3} r_{4} s_{3} s_{4}\right\}\right] \\
r_{j}= & \cos \frac{P h_{j}}{V_{j}}, s_{j}=\sin \frac{P h_{j}}{V}, \alpha_{j}=\frac{\rho_{j+1} V_{j+1}}{\rho_{j} V_{j}}
\end{aligned}
$$

である. $\rho_{j}, V_{j}$ および $h_{j}$ はそれぞれ第 $j$ 層の密度, せん断波速度および層厚を示す.一方, 基盤面における 絶対振幅 $A_{G}$ と入力波の振幅 $A_{1}$ との比は次式で与え られる。

$$
\frac{A_{G}}{A_{1}}=\frac{2 \sqrt{F}}{\sqrt{ } B}
$$

ここに,

$$
\begin{aligned}
F= & \left\{r_{2}\left(r_{3} r_{4}-\alpha_{3} s_{3} s_{4}\right)-\alpha_{2} r_{2}\left(r_{4} s_{3}+\alpha_{3} r_{3} s_{4}\right)\right\}^{2} \\
& +\left(K_{1}{ }^{2}+K_{2}{ }^{2}\right)\left\{r_{2}\left(r_{4} s_{3} \alpha_{3}+r_{3} s_{4}\right)^{2}+\alpha_{2}{ }^{2} s_{2}\left(s_{3} s_{4}\right.\right. \\
& -\alpha_{3} r_{3} r_{4}{ }^{2}+2 \alpha_{2} r_{2} s_{2}\left(r_{3} s_{4}+\alpha_{3} r_{4} s_{3}\right)\left(\alpha_{3} r_{3} r_{4}\right. \\
& \left.\left.-s_{3} s_{4}\right)\right\}-2 K_{2}\left[\alpha_{3} r_{3} s_{3}\left(r_{2}{ }^{2}-\alpha_{2}{ }^{2} s_{2}{ }^{2}\right)\left(r_{4}{ }^{2}-s_{4}{ }^{2}\right)\right. \\
& +r_{4} s_{4}\left\{r_{2}{ }^{2}\left(r_{3}{ }^{2}-\alpha_{3}{ }^{2} s_{3}{ }^{2}\right)+\alpha_{2}{ }^{2} s_{2}{ }^{2}\left(s_{3}{ }^{2}-\alpha_{3}{ }^{2} r_{3}{ }^{2}\right)\right\} \\
& +\alpha_{2} r_{2} s_{2}\left\{\alpha_{3}\left(r_{3}{ }^{2}-s_{3}{ }^{2}\right)\left(r_{4}{ }^{2}-s_{4}{ }^{2}\right)\right. \\
& \left.\left.-2\left(1+\alpha_{3}{ }^{2}\right) r_{3} r_{4} s_{3} s_{4}\right\}\right]
\end{aligned}
$$

である．また，堤体底面での振幅 $U_{0}$ と入力波の振幅 $A_{1}$ との比は次のように表わされる. 


$$
\frac{U_{0}}{A_{1}}=\frac{2}{\sqrt{B}}
$$

式 (7) および（8）において， $\alpha_{1}=1$ として $h_{2}=0$ す なわち，

$$
r_{4}=\cos \frac{P h_{2}}{V_{2}}=1, s_{2}=\sin \frac{P h_{2}}{V_{2}}=0
$$

とおけぼ，三層地盤の解となり，さらに $h_{3}=0, \alpha_{2}=1$ とすれば二層地盤の解である式 (5) に一致する.ここで も， $K_{1}$ および $K_{2}$ を含む項は地盤振動に及ぼす堤体の 影響を示すものであり，土構造物と地盤の動的相互作用 が数式的に表現されている.したがって, 式（8）におい て $K_{1}$ および $K_{2}$ を 0 とすれば, 堤体の影響のない場合 の地表面の振幅が得られる. 以上述べた理論解は, あく までもごく単純化されたモデルに基づくものであり, 適 用する場合に注その条件を十分考慮して用いる必要があ ることは言を待たない。

\section{3. 二層地盤上の堤体の振動性状}

\section{（1）堤体と地盤の動的相互作用}

堤体の振動性状に及ぼす地盤の影響については，地盤 および堤体を前節で述べたように単純なモデルに置き換 えることによって比較的簡単な関係式を用いて計算する ことが可能となる.一般には沖積地盤は地表層の層数も 多く複雑であり，モデル化して計算を行う場合にもパラ メーターが多くなり煩雑である. そこで, 地表層が一層 である二層地盤を例にとり，地盤特性がどのように堤体 の振動に影響するかについて検討してみた。

いま，仮に高さ $8 \mathrm{~m}$ の三角形の堤体が厚さ $8 \mathrm{~m}$ の地 表層の上に構築されているものとして, 堤体の密度を $18 \mathrm{t} / \mathrm{m}^{3}$, せん断波速度を $178 \mathrm{~m} / \mathrm{s}$ と仮定する. 地表層 の密度は $1.6 \mathrm{t} / \mathrm{m}^{3}$, せん断波速度は $250 \mathrm{~m} / \mathrm{s}$ とし, 基 盤層については前者を $2.0 \mathrm{t} / \mathrm{m}^{3}$, 後者を $1000 \mathrm{~m} / \mathrm{s}$ とす る. 粘性減衰は堤体についてのみ考えて $5 \%$ とし, 式 （5）を用いて 5 次までの和をとって計算を試みた，図一 2 は，余弦入力波の振幅に対する堤頂あるいは地表面の

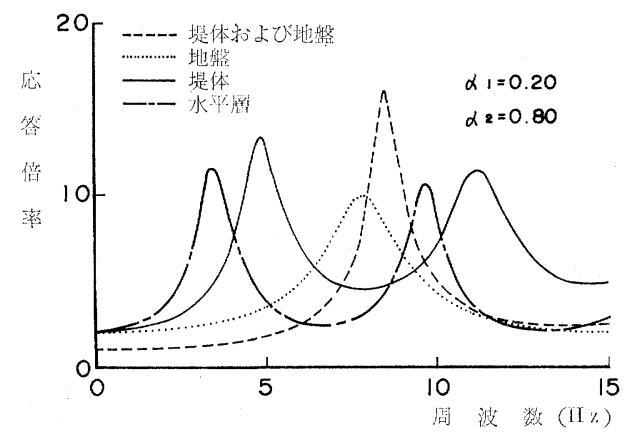

図一2 堤体と地盤の動的相互作用
応答の振幅の比率すなわち応答倍率と入力波の周波数と の関係を示したものである.このときの堤体だけを取り 出して考えたときの固有振動数は図一2 の破線で示すよ らに $8.5 \mathrm{~Hz}$ であり, また, 堤体が存在しないと仮定し たときの地表層の固有振動数は同図中点線で示すごとく $7.8 \mathrm{~Hz}$ である. このように，2つの振動系はきわめて 近い固有振動数を有しているが，この系全体で考えたと きの堤頂での固有振動数は 図一2の実線で示すように 1 次が $4.8 \mathrm{~Hz} ， 2$ 次が $11.2 \mathrm{~Hz}$ となる.この例で明らか なように，堤体地盤系の応答は必ずしも堤体あるいは地 盤の個々の振動系の応答の重㸚合わせでは求められない 場合があることが知られる。

一方, 盛土を盛土高さに等しい厚さの半無限平行層に 置き換えて応答を求める手法もあるが ${ }^{13)}$ ，この場合の忘 答は三角形の堤体を考えた場合と明らかに異なる.上記 の例で堤体を堤高 $H$ に等しい厚さの土層として考えた 場合には，基盤上に二層がある三層問題となり，このと きの堤頂に対応する地表面での応答は,

$$
\frac{U}{A_{1}}=\frac{2}{\sqrt{E}}
$$

となる.ここに，

$$
\begin{aligned}
E= & \left(\cos ^{2} \frac{P h}{V_{2}}+\alpha_{1}{ }^{2} \sin ^{2} \frac{P h}{V_{2}}\right) \cos ^{2} \frac{P H}{V_{3}} \\
& +\alpha_{2}{ }^{2}\left(\sin ^{2} \frac{P h}{V_{2}}+\alpha_{1}{ }^{2} \cos ^{2} \frac{P h}{V_{2}}\right) \sin ^{2} \frac{P h}{V_{2}} \\
& -2 \cos \frac{P h}{V_{2}} \sin \frac{P h}{V_{2}} \cos \frac{P H}{V_{3}} \sin \frac{P H}{V_{3}} \\
& \cdot \alpha_{2}\left(1-\alpha_{1}{ }^{2}\right)
\end{aligned}
$$

である.上式において $\alpha_{2}$ および $H$ を含む項は，堤体 を理想化した平行層の影響を示す項であり，式 (5)にお ける堤体の影響を示す項とは異なった現われ方をしてい る. 比較のために堤体を水平層と仮定した場合の応答を 求め, 図一2 に一点鎖線で示したが, 固有振動数は 1 次，2次ともに堤体モデルよりもかなり小さく，また， 最大応答倍率もやや小さくなる傾向がみられ, 水平層の モデル化が必ずしも適切であるとはいえないことが知ら れる.

\section{（2）堤体の振動に及ぼす基礎地盤の影響}

堤体の応答特性は, 堤体と地盤の動的相互作用により 地盤の動的特性によってかなり影響されることは前に述 べたとおりである。本節では，このような堤体振動に及 ぼす基礎地盤の特性の影響について前節と同様のモデル について試算した結果を述べる.

堤体および地表層の諸元は同一で, 基盤層の弾性波速 度 $V_{1}$ が変化して基盤と地表層の振動インピーダンス比 $\alpha_{1}$ の值が変化した場合を考える.このとき, 基盤面の 入力振幅 $A_{1}$ に対する堤体頂部での応答 $A_{c}$ の倍率は 


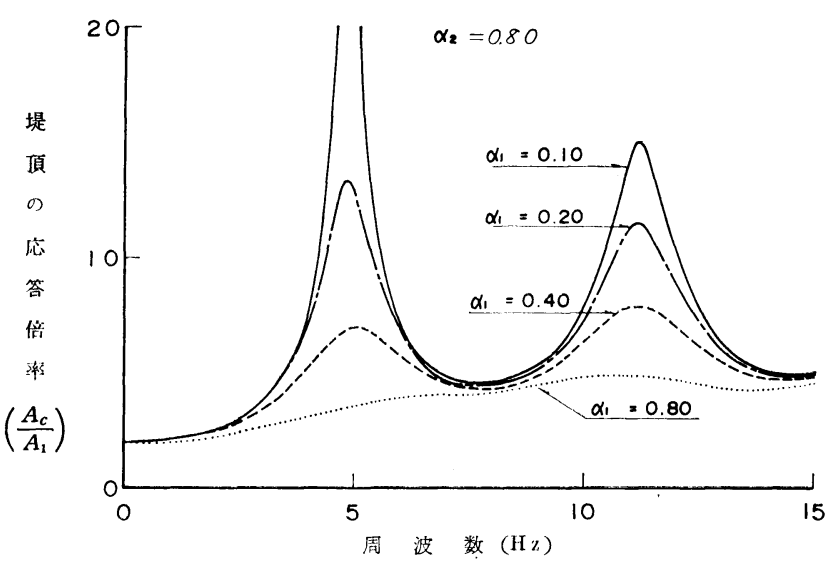

図一3堤体の振動に及ぼす基盤の影響

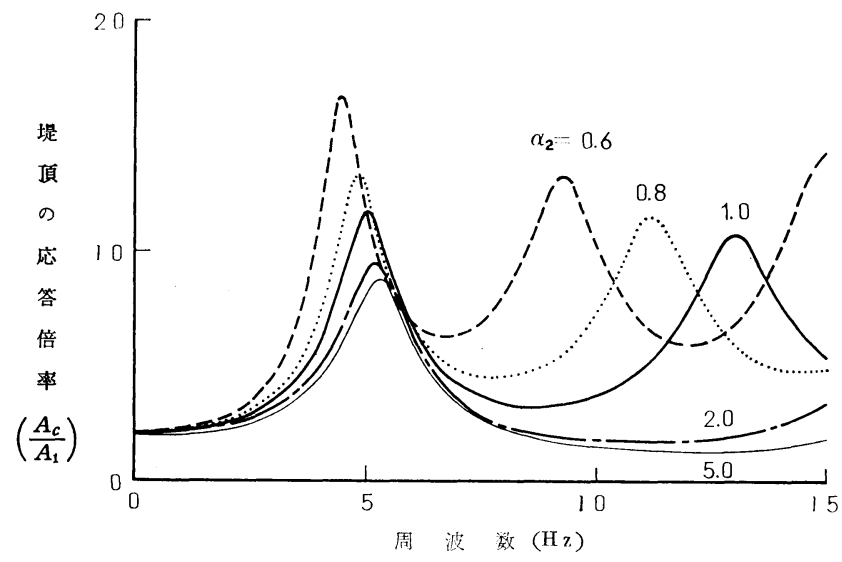

図一4＼cjkstart堤体の振動に及ぼす地盤条件の影響

図一3 に示すようになり，応答曲線は $\alpha_{1}$ の值に応じて かなり変化する．すなわち， $\alpha_{1}$ が小さければ明瞭な共 振状態が現われてくるが， $\alpha_{1}$ が大きい場合には応答曲 線に顕著なピークがみられなくなる．応答曲線の形をみ る限りでは， $\alpha_{1}$ が大きい場合は応答倍率も小さく，大 きな減衰が働いているように見受けられるが，仮定では 堤体の減衰は $5 \%$ と一定にしているので，この減衰は 波の地下逸散によるものと考えることができる.このこ とは, 堤体の応答を求めるうえで粘性減衰の効果ととも に地下逸散減衰の影響を十分考慮する必要があることを 示している.

一方, 同じ地盤モデルに対して堤体材料の弾性波速度 $V_{3}$ を変えて種々な $\alpha_{2}$ の值に対して基盤の入力振幅 $A_{1}$ に対する堤頂での応答の振幅 $A_{c}$ を求めたものが 図一4 である.ここでは基盤層のせん断波速度 $V_{1}$ は 1000 $\mathrm{m} / \mathrm{s}$ としている.この結果によれば, 堤体の剛性が低下 して振動インピーダンス比 $\alpha_{2}$ が減少すると固有振動数 が小さくなり最大応答倍率が大きくなるとともに, 高次 の固有振動が現われてきて全体的に応答倍率が高くなる

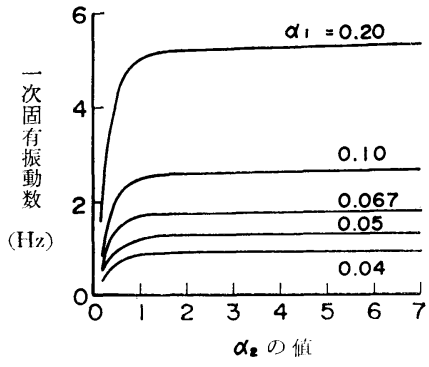

図-51 次固有振動数と振動インビー ダンス比との関係

傾向がみられる。ここでも $\alpha_{2}$ が大きくなると 态答曲線は低い山状をなし，見掛け上減衰が大 きいような傾向を示し，地下逸散減衰の影響が 明瞭にみられる。これらのことは，弱い材料で 堤体を構築したり，締固めが不十分で密度が小 さかったりすることが，振動的にきわめて不利 であることを示している.

このように振動インピーダンスが堤体の応答 特性に及ぼす影響がきわめて大きいので， $\alpha$ および $\alpha_{2}$ の值の変化によってどのように応答 特性が変化するかを調べてみた．ただし，基盤 層の密度および弾性波速度は一定とし，それぞ れ $2.0 \mathrm{t} / \mathrm{m}^{3}, 1000 \mathrm{~m} / \mathrm{s}$ と仮定した. 図一5 は， 堤体の 1 次固有振動数が $\alpha_{1}$ および $\alpha_{2}$ の值に よってどのくらい変化するかを示したものであ る.この図から明らかなように 1 次固有振動数 は $\alpha_{1}$ の值によってかなり異なり， $\alpha_{1}$ が 増加 するにつれて 1 次固有振動数は増大する傾向に ある. また， $\alpha_{1}$ が一定の場合， $\alpha_{2}$ の值が増加すると 1 次固有振動数は増大するが，この傾向は $\alpha_{2}$ が 1.5 ない し 2 よりも小さな值で特に顕著であり，2 以上の $\alpha_{2}$ の 值に対してはあまり変化がなく,ほぼ一定の固有振動数 となる。

図一6 は同様にして得られた 1 次固有振動時の基盤の 入力振幅 $A_{1}$ に対する堤頂における応答 $A_{c}$ の比率の最 大值，すなわち，最大応答倍率 $\left(A_{c} / A_{1}\right)_{\max }$ を $\alpha_{1}, \alpha_{2}$ をパラメーターに記したものである． $\alpha_{1}$ が大きい場合 には最大応答倍率は小さくなり，また， $\alpha_{2}$ が小さい場 合には応答倍率はきわめて大きい值となるが， $\alpha_{2}$ の 増 加とともに減少しほぼ一定值となる傾向がみられる. し たがって，堤体剛性が地表層のそれより低い場合，ある いは地表層の剛性が基盤のそれよりかなり小さい場合に は, 比較的振動数の小さな範囲で共振状態が起こり, し かもその応答倍率がきわめて高くなるので, 軟弱地盤上 の堤体が震害を受けやすいことの一つの説明となり得 る。

堤体の応答特性に及ぼす地表層の厚さの影響を調べる 


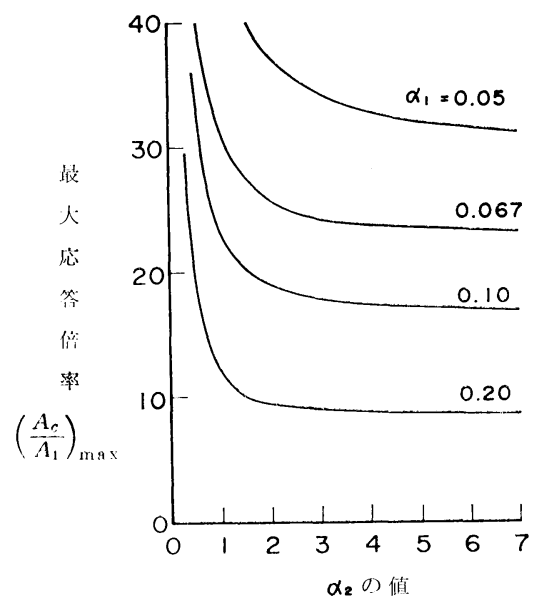

図 6 最大応管倍率と振動インピーダンス比との関係

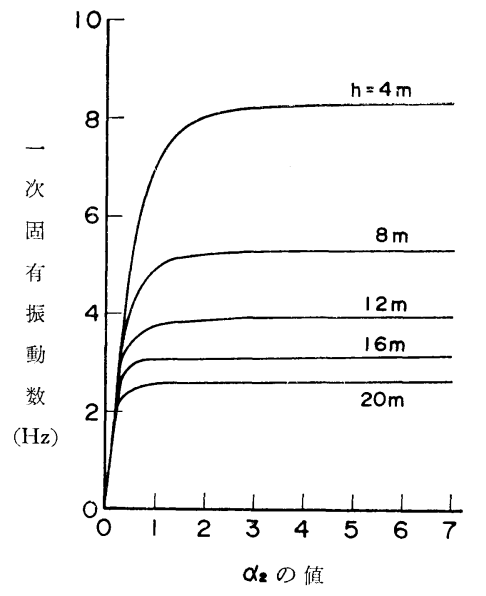

図一7 1 次固有振動数に及ぼす地衰層の影響

ために， $\alpha_{1}$ を 0.2 と一定として地表層の厚さと $\alpha_{2}$ の 值を変化させて計算を行ってみた. 図一7 は 1 次固有振 動数が $\alpha_{2}$ の值によってどのように変化するかを地表層 の厚さをパラメーターにして記したものである． $\alpha_{2}$ が 1 以下の值では固有振動数は $\alpha_{2}$ の増加に伴い急激に増 加するが， 2 以上の值に対してはほぼ一定值となること が知られる. また, この固有振動数は堤体がない場合の 地表層の自由振動数と比較してかなり小さいが, 地表層 の厚さに反比例して層厚が大きいほど小さくなる傾向が みられる. 図一8 は，同様に 1 次固有振動のときの基盤 入力に対する堤頂の最大応答倍率 $\left(A_{c} / A_{1}\right)_{\text {max }}$ を示し たものである. $\alpha_{2}$ が 1 以下では最大忘答倍率は非常に 大きな值をとるが， $\alpha_{2}$ の増加に伴い急速に減少する.

この傾向は地表層の厚さに応じてやや異なり， $\alpha_{2}$ が 1.5 より大きい場合は地表層が厚いほど応答倍率が大き いが， $\alpha_{2}$ が 1.5 より小さい場合は逆の関係になる.こ れらのことから，地表層の剛性が一定の場合には堤体材 料の剛性を地表層のそれより高く寸れば，応答倍率が低

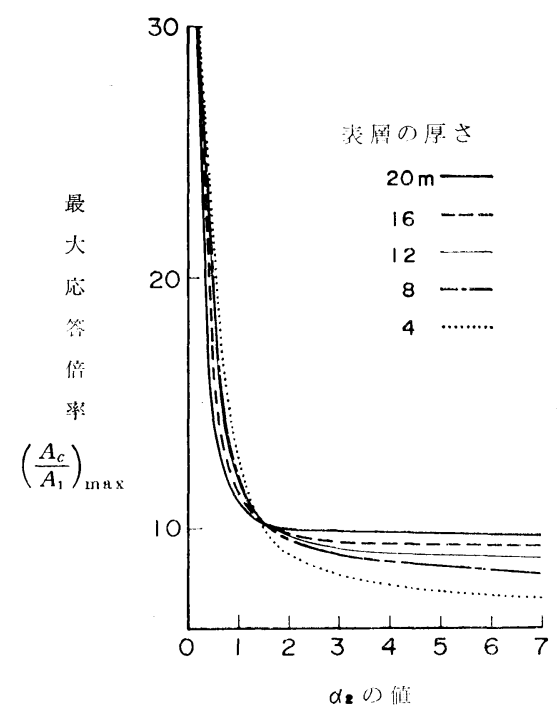

図 8 最大応答倍率に及ぼす地表層の影響

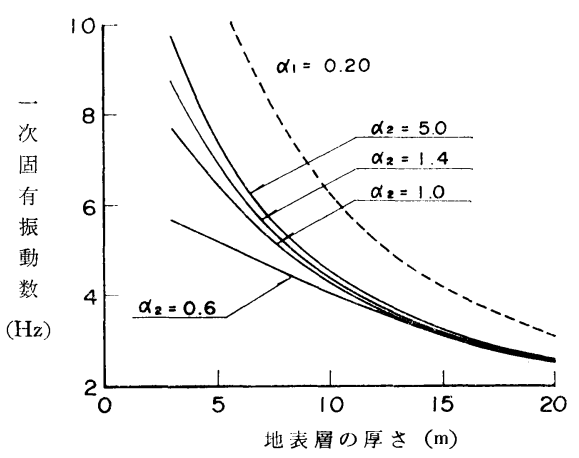

図一91 次固有振動数と地表層厚との関係

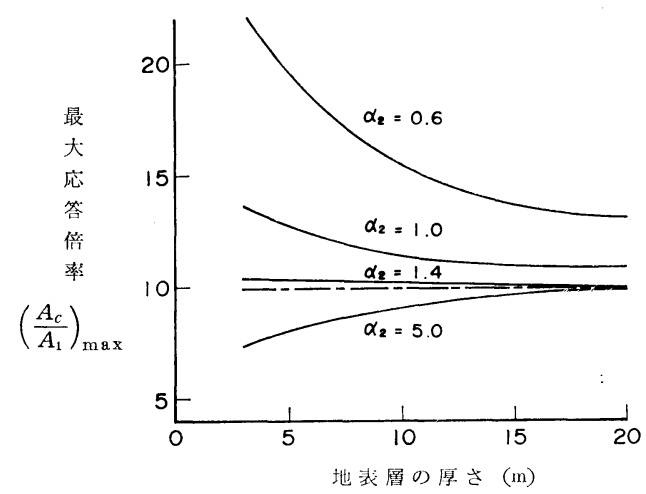

図一10 最大応答倍率と地表層厚との関係

くなるので，堤体の耐震性を高めることになることがよ く理解される.

地表層の厚さの影響をみるために，横軸に地表層の厚 さをとり, 縦軸に 1 次固有振動数㧍よび最大応答倍率 $\left(A_{c} / A_{1}\right)_{\max }$ をとったものが図一9 および 10 である. 図一9 は $\alpha_{2}$ をパラメーターとして示してあるが，地表 
層の厚さが大きくなると 1 次固有振動数は急激に小さく なる．図中の破線惿体の影響のない場合の地表層の固 有振動数を示したものであり, 堤体地盤系の固有振動数 との 差異が明膫にみられる. 1 次固有振動数に及ぼす ａ，影響は層厚の小さなところでは 顕著であるが，層 厚が大きくなるとほとんど差異がなくなる。図一10は 同じく最大応答倍率 $\left(A_{c} / A_{1}\right)_{\mathrm{max}}$ と層厚の関係を記し たものであるが， 答倍率はかなり大きく, かつ, 地表層が薄いほど応答倍 率は高い。しかし， $\alpha_{2}$ が大きくなると念答倍率は小さ くなり， $\alpha_{2}$ が 1.5 より大きい場合には, 地表層の厚さ が大きいほど最大忘答倍率が高くなる傾向がみられる。 同図中の破線は, 堤体の影響のない場合の地表層の最大 态答倍率を示したものであるが， $\alpha_{2}$ が 1.5 付近での堤 体地盤系の最大応答倍率とほぼ等しくなり, 地表層の厚 さに無関倸に一定值となる.

これらの結果によれば, 地表層の剛性が一定の場合に は $\alpha_{2}$ を大きくすればするほど振動に対しては有利にな ると考えられるが， $\alpha_{2}$ が 1.5 ないし 2 以上であれば応 答倍率は低下してほぼ一定值に近くなるので, 実際上は 堤体材料と地表層のせん断波速度の比を 1.5 程度にする ことができれば，最も実質的に耐震性を向上させること になるものと考えられる.

\section{4. 実測結果との比較}

これまで述べた理論がどの程度実際の現象と対応する かを調べるために，八郎潟中央干拓堤防の正面堤防を例 にとり理論值と実測值との比較を試みた。 八郎潟干拓堤 防の一部はすでに述べたように男鹿西方沖地震および新 潟地震により被災したが, この正面堤防付近ではほとん ど被害が発生しなかった。これは，正面堤防付近では軟 弱層が厚いためにあらかじめその影響を十分考慮して設 計がなされていたためであると考えられている.この正 面堤防においては著者らによる常時微動測定 ${ }^{14)}$ のほかに 河上ら ${ }^{15)}$ および浅田ら ${ }^{16), 17)}$ による地震動観測や常時微 動観測が行われている. 後者の観測点付近では, 厚さ約 $30 \mathrm{~m}$ の軟弱地盤上に約 $4 \mathrm{~m}$ の敷砂をして，その上に高 さ約 $6 \mathrm{~m}$ の堤体が砂質土で築造されている.この観測 点における地盤の卓越周期は, 河上らの報告 ${ }^{18)}$ とよれば $1.60,0.80,0.55,0.25$ および $0.16 \mathrm{~s}$ である. 堤頂部 分における堤軸直角方向の水平動についての浅田らの観 測結果 ${ }^{16)}$ および著者が解析区間を変えて計算した 1978 年 2 月 10 日の宮城県沖地震の解析結果の一例を 図-11 に示す.この図から明らかなよらにフーリエスペクトル のピークは $2.50,1.25,0.80$ および $0.45 \mathrm{~s}$ 付近にあ り,これらが堤頂での卓越周期と考えることができる.

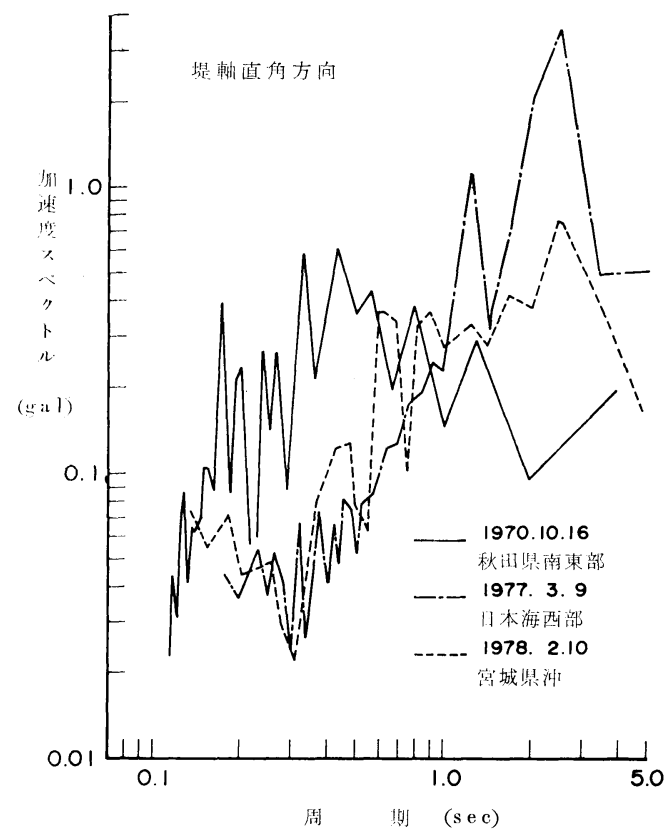

図一11堤頂で観測された地震波のスペクトル (浅田らによる ${ }^{19}$ )

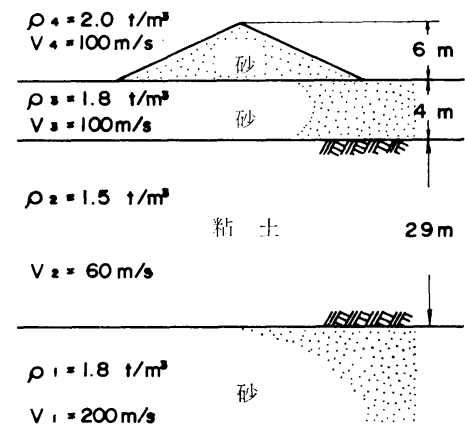

図一12 干拓堤防と地盤のモデル

すでに述べた多層地盤上の堤体の振動解に基づいて, 図一12 に示すような三層地盤と堤体のモデルを考えて 周期応答を求めてみた. 堤体および地盤の諸定数は河上 らの実測データ1)を若干修正して用いている。なお，堤 体の振動については前節と同様に減衰率は $5 \%$ とし， 5 次までの振動を考慮した. 図一13 には基盤入力に対す る堤体頂部における応答曲線, 堤体の影響のない場合の 地盤の応答曲線および堤体自体の応答曲線が，それぞれ 実線，破線および一点鎖線で示してある。堤体の影響 のない地盤だけの固有周期は $2.30,0.74,0.44$ および $0.31 \mathrm{~s}$ であるのに対し, 堤体地盤系の固有周期は 2.50 , $0.80,0.46$ および $0.32 \mathrm{~s}$ となっている.ただし，堤体 自身の固有周期は， 0.16 および $0.07 \mathrm{~s}$ である. 理論的 に求められた固有周期は，図一11 で得られた堤体での 実測の卓越周期にきわめて近い值となっている. 実測値 


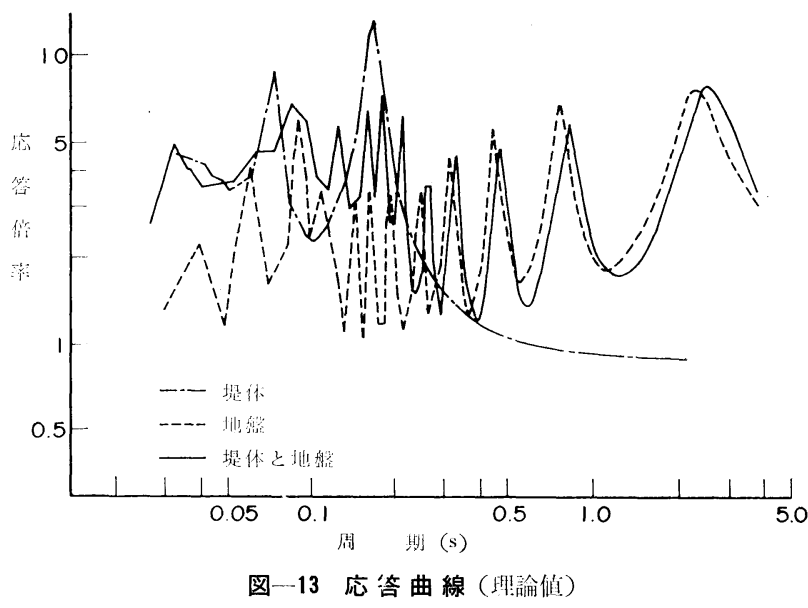

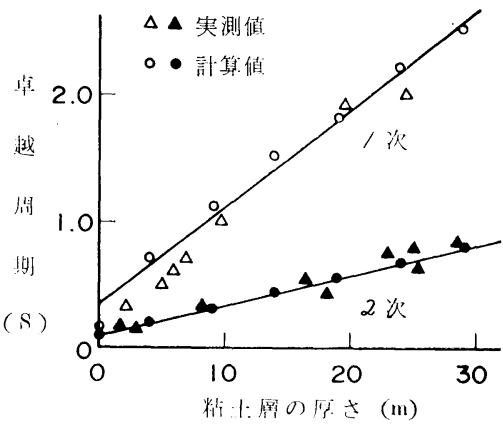

図 15 固有周期の実測值と理論値

1 次卓越周期は理
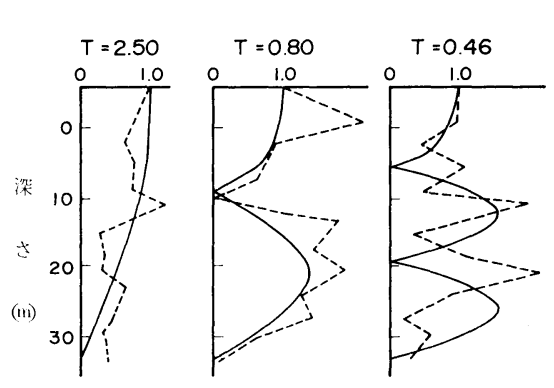

風 $T=0.32$

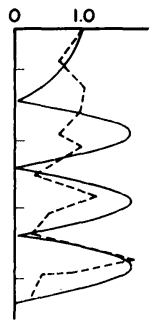

図一14振動モードの実測値と理論値

の中には, 一部理論值に対応のない卓越周期があるが, これはここで考えている以外の振動形に由来するもので あろら.

固有振動時の振動形を比較するために堤体および地盤 内の振幅分布を求め, 理論值を実線で, また, 実測值を 破線で示したものが 図一14 である.ここで, 実測值は 河上らによって得られた地中常時微動の変位スペクトル から, 各周期について堤頂部におけるスペクトルを 1 と して, 各深さにおけるスペクトルの比を求めて記したも のである.この図から 1 次から 4 次までの各固有周期に おける実測振幅分布が計算で求めた理論振幅分布とよく 一致していることが知られる.

中間に存在する軟弱な粘土層の厚さを変化させたとき の計算で求められた 1 次および 2 次の理論固有周期と層 厚との関係を示したものが図一15 である. 計算で求め た堤体地盤系の固有周期は, ほぼ粘土層厚に比例するこ とが知られる. 同図中には, 八郎潟干拓堤防の正面堤防 およびその他の地点（たとえば西部承水路堤防）で測定 された常時微動の卓越周期と軟弱層の厚さとの関係がプ ロットされている.ここで 1 次固有周期に対応する実測 值は河上らの報告 ${ }^{19}$ によるものである.この図から明ら かなように, 計算值と実測值とは比較的よく一致してい る.ただし, 粘土層の厚さの小さいところでは, 実測の 論值よりやや小さ く,この場合はむ

しろ堤体を無視した地盤 の 1 次固有周期に近いも のと考えられる.しか し, 粘土層厚の小さなと ころでの常時微動の卓越 周期を 1 次と 2 次に判別 するのは困難であり, 主

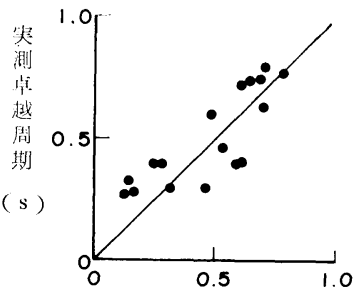

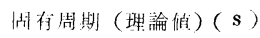

図一16 固有周期の実測値と 理論値の比較 観の混じる可能性もある.

図一16 は，実測卓越周期と地盤構造から理論的に求 めた固有周期との関係を記したものである、計算上, 上 部の砂層の厚さおよび各土層の弾性波速度を一定とした ためやや誤差は認められるものの，ほぼ一対一の対応が 得られている.

このように, 単純なせん断波の仮定を用いて堤体と地 盤からなる振動系の応答特性を求めた結果が, 地震や常 時微動観測による卓越周期や振動形と比較的よく一致し ていることから,この解析手法を用いて, 中小の地震に 対する堤体の応答を計算することは可能である.しかし ながら, 被害が生じるような大地震の際の挙動について は, 土材料の非線形性や減衰特性など，ほかに考慮すべ き多くの要因があるので，この手法をそのまま適用する ことは適当ではない.

\section{5. 地震応答解析の一例}

成層地盤で定常応答特性が知られている場合に, 地震 入力に対する過渡応答を求める手法は, Shnabel ら ${ }^{20)}$ によって提示されている. すなわち, 系の周波数応答 $A(\omega)$ が知られている場合, 入力波のフーリエスペクト ル $Y(\omega)$ とかけ合わせてスペクトルを求め,

$$
\dot{U}(t)=\sum A\left(\omega_{i}\right) Y\left(\omega_{i}\right) \cos \left(\omega_{i} t+\phi_{i}\right)
$$

により周波数領域より時間領域に変換する手法である. この方法を用いて前節で用いた 図一12 のモデルについ 
て，堤体の応答に及ぼす粘土層の厚さの影響をみるため に粘土層厚を変化させて加速度応答を求めてみた. 入力 に用いた地震波形はエルセントロ NS 成分, 十勝沖地 震八戸港 $\mathrm{EW}$ 成分および宮城県沖地震塩釜港 $\mathrm{EW}$ 成 分の 3 種であり，基盤に直接入力することとした．解析 は, 0.01 秒間隔に 1024 点すなわち 10.24 秒間の記録 を用い， $15 \mathrm{~Hz}$ までの周波数成分についての合成を行 い, 入力の最大加速度 $\left(A_{i}\right)_{\max }$ に対する堤頂の応答の 最大加速度 $\left(A_{c}\right)_{\max }$ の比率を求めた.

この結果得られた堤頂における最大加速度応答倍率を 粘土層の厚さに対して記したものが 図一17 である.堤 頂における最大加速度応答倍率は，ほぼ 3 8 の間にあ り，入力地震波によりその傾向は異なるが，全体的にみ れば軟弱層が厚いほど応答倍率がやや減少する傾向がみ られる.これは, 粘土層の厚さに対応して固有振動数が 小さくなるので比較的高い周波数成分の増幅が小さくな り, 最大加速度応答倍率がやや減少するものと考えられ る. 加速度応答倍率が多少低下しても固有振動数が小さ くなれば変位応答は大きくなることが考えられるので， 粘土層が厚いほど最大応答変位は大きいことは予想され る. 堤体の震害と軟弱層の厚さとに相関があるものとす れば, 最大加速度ばかりでなく最大変位も耐震工学上重 要な要因であるといえよう.

これまで述べた結果はあくまで線形の範囲での論議で あり, 被害の発生するような大きな入力地震に対しては 地盤や堤体の材料が非線形性を示すことは十分考えられ ることである. その場合, 最大加速度応答は線形応答よ りも低下することが考えられるので, この解析法による 結果は最大加速度応答の上限值を与えるものと考えるの が妥当である.したがって，この方法で堤体の設計加速 度を求めた場合には，かなり安全側の設計になることは 否めない. しかしながら, 従来の河川堤防や干拓堤防の

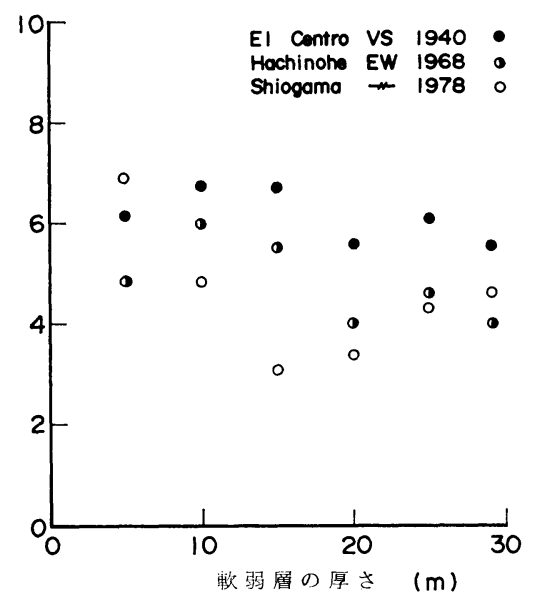

図-17 軟弱層の厚さと最大加速度応答倍率
耐震設計では，地盤種別の考慮はなされてはいるもの の，地盤条件の影響についてはあまり明確にはされてい なかったので, 本研究はこれらの影響を知るための一手 法として有用であると考える.

\section{6. 結 論}

せん断ばりの理論を用いてせん断波が入射した場合の 堆積地盤上の堤体の地震応答特性を調べた結果, 次のよ うな結論が得られた。

（1）堤体と地盤の動的相互作用により, 堤体の応答 特性は基礎地盤の動特性によって大きく影響される.

（2）二層地盤モデルによれば，堤体-地盤系の応答 特性は主として地表層および堤体材料の剛性によって定 まり, 地表層が軟弱なほど, また, 堤体材料の剛性が地 表層のそれと比べて小さいほど固有振動数が小さくな り, 応答倍率が高くなる.

（3）地表層の剛性が一定の場合，堤体材料の剛性が 大きいほど系の固有振動数は高くなり応答倍率は低下す る.この傾向は, 堤体と地表層のインピーダンス比が 2 付近でほぼ一定となるので, 堤体材料の $\mathrm{S}$ 波速度を地表 層のそれの約 2 倍程度にすれば, 最も効果的に耐震性を 高めることになる。

（4）本理論の妥当性を検討するために, 八郎潟干拓 堤防における地震観測結果および地中常時微動測定結果 とこれを単純化したモデルによる計算結果との対比を行 った.この結果, 理論值と実測値とが比較的よく一致す ることが認められた.

（5）このモデルにおいて粘土層の厚さを変化させて 地震時の最大加速度応答值を求めた結果, 堤体頂部にお ける最大加速度応答は, 入力地震波によって異なるが, 粘土層の厚さが増大するとやや減少する傾向が認められ た.

本論文をまとめるにあたり, 貴重な実測データの提供 をいただいた東北工業大学 浅田秋江教授ならびに 計算 の一部を実施していただいた清水建設（株）の栗田守朗 氏に深心の感謝の意を表します.

\section{参 考 文 献}

1）表 俊一郎：東海地震及び三河地震による地震危険率の 比較, 地震研究所彙報, 24 号, pp. 87 98, 1946.

2）河角 広: 東京の震害分布と地盤について, 建築雑誌, 66 輯, 773 号, pp. 8 15, 1951.

3）金井 清・森下利三: 震害と地盤の関倸 第 2 報, 地震研 究所彙報, 41 号, pp. 271 285, 1963.

4）金井 清: 木造家屋の震害について, 地震研究所彙報, 29 号, pp. 215 222, 1951.

5）河上房義・浅田秋江・柳沢栄司：堤防の耐震性と常時微 動の関倸化ついて, 土と基礎, Vol. 14, No. 9, pp. 19 $\sim 25,1966$. 
6) Hoshiya, M. : Seismic Damage of Embankment by Quantification Analysis, Proc. of U.S.-Japan Seminar on Earthquake Engg. Research with Emphasis on Life Line System, pp. 141 156, 1975.

7）河上房義・浅田秋汇：柳沢栄司・森 芳信：1968 作一个勝

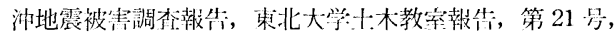
pp. $1 \sim 40,1969$.

8）河，上房義・浅出秋江－森 芳信：一勝沖地震の被㫪索涭 けた馬淵川堤防の常時微動特性, 東北地域災害科学研究 研究報告: 昭和 43 年度, pp. 126 136, 1969.

9）浅田秋江－河上房義：地盤震動特性に関与る 察，士木学会論文報告集，第 236 号，pp. 93 107, 1975

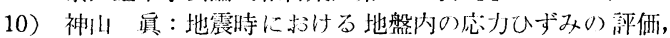
士末学全論文報告集，第 250 号，pp. 9 23，1976.

11) Okamoto, S., C. Tamura and K. Kato : Earthquake Response of Fill Type Dam, Proc. of 3rd Japan Earthquake Engg. Symposium, pp. 461 468, 1970.

12）柳沢栄司：士構造物の振動特性に及ぼす基礎地盤の影響, 第 13 问土:筫丁:学研究発表会講演集, pp. 1033 1036, 1978.

13）たとえば, 大橋 猛・堀越信雄・麓 秀夫 : 高盛土の地 震時挙動の予測, 第 14 回土質工学研究発表会講演集, pp. 1329 1332, 1969.

14）文献 5) に同じ.

15）河上房義：八郎潟干拓堤防正面堤地震動観測，昭和 45 年 度報告書, 1971 .

16）浅田秋江・栗原益男：八郎潟干拓堤防における 地震動観 測例, 土木学会第 33 回年次学術講演会講演概要集 III, pp. $174 \sim 175,1978$.

17）河上房義・浅田秋江：軟弱地盤上に築造された八郎潟干
拓堤防の耐震性について, 土と基礎, Vol. 123, No. 12, pp. $43 \sim 49,1975$.

18）河上房義・浅田秋江：八郎潟干拓堤防正面堤地震動観測 昭和 47 年度報告書, 1973 .

19）河上房義・浅田秋汇・森 芳信：軟弱地盤」：の盛土の霹

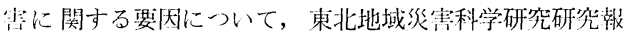
点, 第 8 巻, pp. 157 164, 1962.

20) Shnabel, P.B., J. Lysmer and H.B. Seed : SHAKE A Computer Program for Earthquake Response Analysis of Horizontal Layered Sites, Report No. EERC 72-12 Earthquake Engineering Research Centre of Univ. of California, pp. 9 10, 1972.

21）柳沢栄间：多層地盤士：ひ堤体の振動性状について，士 木学会第 33 问年㳄学術講演会講演概要集 III, pp. 168 $169,1978$.

22) 柳源栄问：多層地盤上の堤体の地震态答特性について, 第 5 间日本地震T学シンポジウム論文集, pp. $793 \sim 800$, 1978.

23）柳汇栄间：土構造物の振動に及ぼす地盤振動の影響，符 11 回土質工学研究発表会講演集, pp. 841 844, 1976.

24）柳沢栄司：軟弱地盤上の土構造物の応答特性, 第 14 问地 震工学研究発表会講演集, pp. 69 72, 1976.

25）柳沢栄司：軟弱地盤上の土構造物の振動性状について, 土木学会第 31 回年次学術講演会講演概要集 III, pp. 261 $\sim 262,1976$.

26）柳沢栄司：土構造物の振動性状におよぼす基礎地盤の影 響, 土木学会第 32 回年次学術講演会講演概要集 III, pp. 287 288, 1977. 